Pacific Journal of Mathematics

A NOTE ON WEAK SEQUENTIAL CONVERGENCE

January 1962 


\title{
A NOTE ON WEAK SEQUENTIAL CONVERGENCE
}

\author{
R. D. McWilliams
}

1. Let $\mathrm{X}$ be a real Banach space, $J_{X}$ the canonical mapping from $X$ into $X^{* *}$, and $K(X)$ the set of all elements $F$ in $X^{* *}$ which are $X^{*}$-limits of sequences in $J_{X} X$. Thus $F \in K(X)$ if and only if there exists a sequence $\left\{x_{n}\right\}$ in $X$ such that

$$
F(f)=\lim _{n} f\left(x_{n}\right)
$$

for all $f \in X^{*}$. While the closure of $J_{X} X$ in the $X^{*}$-topology is $X^{* *}$ $\left[4\right.$, p. 229], it is not true in general that $K(X)=X^{* *}$. By using properties of the space of continuous real functions defined on a real interval, we shall prove that the subspace $K(X)$ is norm-closed in $X^{* *}$.

2. If $x$ is a bounded real function defined on a closed interval $[a, b]$, let $\|x\|=\sup \{|x(s)|: a \leqq s \leqq b\}$. If $x$ is a bounded Baire function of the first class, then there exists a sequence $\left\{x_{n}\right\} \subset \mathscr{C}[a, b]$ such that $x(s)=\lim _{n} x_{n}(s)$ for all $s \in[a, b]$ and $\left\|x_{n}\right\|=\|x\|$ for all $n[2, \mathrm{p} .138]$. However, if a bounded function $x$ is the pointwise limit of an unbounded sequence of elements of a subspace $X$ of $\mathscr{C}$, then it is not necessarily true that $x$ is the pointwise limit of a bounded sequence in $X$.

Lemma 1. Lex $X$ be a subspace of $\mathscr{C}$, and let $x$ be a real function which is the pointwise limit of a bounded sequence in $X$. Then there exists a sequence $\left\{x_{n}\right\}$ in $X$ such that $x$ is the pointwise limit of $\left\{x_{n}\right\}$ and $\left\|x_{n}\right\|=\|x\|$ for all $n$.

Proof. If $\left\{y_{n}\right\}$ is a sequence in $X$ which converges pointwise to $x$, with $\sup _{n}\left\|y_{n}\right\|=M<\infty$, let continuous functions $\varphi, \varphi_{1}, \varphi_{2}, \cdots$ be defined by

$$
\left\{\begin{array}{l}
\varphi(s) \equiv\|x\| \\
\varphi_{n}(s)=\max \left(y_{n}(s),\|x\|\right)
\end{array}\right.
$$

for all $s \in[a, b]$. Then $\left\{\varphi_{n}\right\}$ converges to $\varphi$ in the $\mathscr{C}^{*}$-topology of $\mathscr{C}$ $[1$, p. 224], and hence [3, p. 36] for each positive integer $n$ there exist nonnegative numbers $a_{n 1}, \cdots, a_{n k_{n}}$ such that

$$
\sum_{k=1}^{k_{n}} a_{n k}=1, \quad\left\|\sum_{k=1}^{k_{n}} a_{n k} \varphi_{n+k}-\varphi\right\|<n^{-1} .
$$

Define $\left\{z_{n}\right\} \subset X$ by

$$
z_{n}=\sum_{k=1}^{k_{n}} a_{n k} y_{n+k}
$$

Received February 2, 1961. 
Then $\left\{z_{n}\right\}$ converges pointwise to $x$, and $-M \leqq z_{n}(s) \leqq\|x\|+n^{-1}$ for each $n$.

If a sequence $\left\{\psi_{n}\right\}$ is now defined in $\mathscr{C}$ by $\psi_{n}=\min \left(z_{n},-\varphi\right)$, an argument like that used with $\left\{\varphi_{n}\right\}$ shows that there exist, for each $n$, nonnegative numbers $b_{n 1}, \cdots, b_{n j_{n}}$ such that

$$
\sum_{j=1}^{j_{n}} b_{n j}=1, \quad\left\|\sum_{j=1}^{j_{n}} b_{n j} \psi_{n+j}+\varphi\right\|<n^{-1} .
$$

If $\left\{u_{n}\right\} \subset X$ is defined by

$$
u_{n}=\sum_{j=1}^{j_{n}} b_{n j} z_{n+j},
$$

then $x$ is the pointwise limit of $\left\{u_{n}\right\}$, and $\left\|u_{n}\right\| \rightarrow\|x\|$ as $n \rightarrow \infty$. Since it may be assumed that $\left\|u_{n}\right\| \neq 0$ for each $n$, the desired sequence $\left\{x_{n}\right\}$ is obtained by defining $x_{n}=\left(\|x\| /\left\|u_{n}\right\|\right) u_{n}$.

3. The conjugate space $\mathscr{C}^{*}$ of $\mathscr{C}$ is equivalent with the space of all finite regular signed Borel measures on $[a, b]$, under a mapping $U$ such that if $f \in \mathscr{C}^{*}$ and $\mu_{f}=U f$, then

$$
f(x)=\int_{a}^{b} x d \mu_{\rho}
$$

for all $x \in \mathscr{C}$ [4, p. 397]. It follows that if $X$ is a closed subspace of $\mathscr{C}$ and $F \in X^{* *}$, then $F \in K(X)$ if and only if there exists a bounded, pointwise-convergent sequence $\left\{y_{n}\right\}$ in $X$ with the property that

$$
F(f \mid X)=\int_{a}^{b}\left(\lim y_{n}\right) d \mu_{f}
$$

for all $f \in \mathscr{C}^{*}$.

Lemma 2. If $X$ is a real Banach space and $F \in K(X)$, then there exists a sequence $\left\{x_{n}\right\}$ in $X$ such that $F$ is the $X^{*}$-limit of $\left\{J_{X} x_{n}\right\}$ and $\left\|x_{n}\right\|=\|F\|$ for all $n$.

Proof. Case 1. If $X$ is a closed subspace of $\mathscr{C}$ and $F \in K(X)$, there must be a bounded, pointwise-convergent sequence $\left\{y_{n}\right\} \subset X$ such that (3.2) holds for all $f \in \mathscr{C}^{*}$. If $x(s)=\lim _{n} y_{n}(s)$ for $a \leqq s \leqq b$, then by Lemma 1 there exists a sequence $\left\{x_{n}\right\}$ in $X$ such that $x$ is the pointwise limit of $\left\{x_{n}\right\}$ and $\left\|x_{n}\right\|=\|x\|$ for all $n$. Thus $F$ is the $X^{*}$-limit of $\left\{J_{X} x_{n}\right\}$ and it is easily verified that $\|F\|=\left\|x_{n}\right\|$ for each $n$.

Case 2. If $X$ is an arbitrary real Banach space and $F \in K(X)$, then there is a sequence $\left\{y_{n}\right\}$ in $X$ such that $F$ is the $X^{*}$-limit of $\left\{J_{X} y_{n}\right\}$. If $Y$ is the closed subspace of $X$ generated by $\left\{y_{n}\right\}$, we can define 
$G \in Y^{* *}$ by

$$
G(f \mid Y)=F(f) \text { for all } f \in X^{*},
$$

and this definition is unambiguous since $F$ is the $X^{*}$-limit of a sequence in $J_{X} Y$. It is easy to verify that $G \in K(Y)$ and $\|G\|=\|F\|$. Since $Y$ is separable, $Y$ is equivalent with a closed subspace of $\mathscr{C}[1$, p. 185], and hence by Case 1 , there is a sequence $\left\{x_{n}\right\}$ in $Y$ such that $G$ is the $Y^{*}$ limit of $\left\{J_{Y} x_{n}\right\}$ and $\left\|x_{n}\right\|=\|G\|=\|F\|$ for all $n$. Finally, if $f \in X^{*}$, then

$$
F(f)=G(f \mid Y)=\lim _{n} f\left(x_{n}\right),
$$

so $F$ is the $X^{*}$-limit of $\left\{J_{X} x_{n}\right\}$, and the lemma is proved.

4. THEOREM. If $X$ is a real Banach space, then $K(X)$ is normclosed in $X^{* *}$.

Proof. If $F \in \overline{K(X)}$, then there is a sequence $\left\{F_{n}\right\}$ in $K(X)$ such that $F_{n} \rightarrow F$ in norm, and $\left\|F_{n}-F_{n-1}\right\|<2^{-n}$ for each $n>1$. If we let $F_{0}=0$, then by Lemma 2 there exists, for each $n \geqq 1$, a sequence $\left\{x_{n k}\right\}$ in $X$ such that $\left\|x_{n k}\right\|=\left\|F_{n}-F_{n-1}\right\|$ for all $k$ and such that $F_{n}-F_{n-1}$ is the $X^{*}$-limit of $\left\{J_{X} x_{n k}\right\}$.

For each $k$ the series $\sum_{n=1}^{\infty} x_{n k}$ converges to an element $x_{k} \in X$ such that

$$
\| x_{k}-\sum_{n=1}^{j} x_{n k}||<2^{-j} \text { for each } j
$$

Given $0 \neq f \in X^{*}$ and $\varepsilon>0$, there exist positive integers $J$ and $K$ such that $2^{-\jmath}<\varepsilon /(3\|f\|)$ and $\left|F_{J}(f)-f\left(\sum_{n=1}^{J} x_{n k}\right)\right|<\varepsilon / 3$ for all $k \geqq K$. Hence for $k \geqq K$,

$$
\begin{aligned}
\left|F(f)-f\left(x_{k}\right)\right| & \leqq\left|\left(F-F_{J}\right)(f)\right|+\left|F_{J}(f)-f\left(\sum_{n=1}^{J} x_{n k}\right)\right| \\
& +\left|f\left(\sum_{n=1}^{J} x_{n k}-x_{k}\right)\right|<\varepsilon,
\end{aligned}
$$

so that $F$ is the $X^{*}$-limit of $\left\{J_{X} x_{k}\right\}$.

\section{REFERENCES}

1. S. Banach, Théorie des opérations linéaires, Warsaw, 1932

2. C. Goffman, Real functions, New York, Rinehart, 1953.

3. E. Hille and R. S. Phillips, Functional analysis and semigroups, Amer. Math. Soc. Colloquium Publications, 31, 1957.

4. A. E. Taylor, Functional analysis, New York, Wiley, 1958. 



\section{PACIFIC JOURNAL OF MATHEMATICS}

\section{EDITORS}

Ralph S. Phillips

Stanford University

Stanford, California

M. G. Arsove

University of Washington

Seattle 5, Washington
A. L. Whiteman

University of Southern Californla

Los Angeles 7, California

Lowell J. Paige

University of California

Los Angeles 24, California

\section{ASSOCIATE EDITORS}

E. F. BECKENBACH

D. DERRY

H. L. ROYDEN

E. G. STRAUS

T. M. CHERRY

M. OHTSUKA

E. SPANIER

F. WOLF

\section{SUPPORTING INSTITUTIONS}

UNIVERSITY OF BRITISH COLUMBIA

STANFORD UNIVERSITY

CALIFORNIA INSTITUTE OF TECHNOLOGY

UNIVERSITY OF CALIFORNIA

MONTANA STATE UNIVERSITY

UNIVERSITY OF TOKYO

UNIVERSITY OF UTAH

UNIVERSITY OF NEVADA

NEW MEXICO STATE UNIVERSITY

OREGON STATE UNIVERSITY

UNIVERSITY OF OREGON

OSAKA UNIVERSITY

WASHINGTON STATE UNIVERSITY

UNIVERSITY OF WASHINGTON

UNIVERSITY OF SOUTHERN CALIFORNIA

AMERICAN MATHEMATICAL SOCIETY CALIFORNIA RESEARCH CORPORATION SPACE TECHNOLOGY LABORATORIES NAVAL ORDNANCE TEST STATION 


\section{Pacific Journal of Mathematics}

\section{Vol. 12, No. $1 \quad$ January, 1962}

Jonathan L. Alperin, Groups with finitely many automorphisms $\ldots \ldots \ldots \ldots \ldots \ldots \ldots \ldots$

Martin Arthur Arkowitz, The generalized Whitehead product ................ 7

John D. Baum, Instability and asymptoticity in toplogical dynamics . . . . . . . . . . 25

William Aaron Beyer, Hausdorff dimension of level sets of some Rademacher series .... $\quad 35$

Frank Herbert Brownell, III, A note on Cook's wave-matrix theorem . . . . . . . . . . . . . 47

Gulbank D. Chakerian, An inequality for closed space curves ................. 53

Inge Futtrup Christensen, Some further extensions of a theorem of Marcinkiewicz ....... 59

Charles Vernon Coffman, Linear differential equations on cones in Banach spaces . . . . . 69

Eckford Cohen, Arithmetical notes. III. Certain equally distributed sets of integers . . . . . 77

John Irving Derr and Angus E. Taylor, Operators of meromorphic type with multiple poles

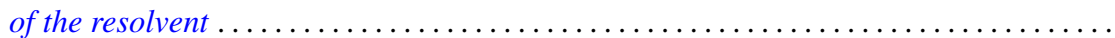

Jacob Feldman, On measurability of stochastic processes in products space .............

Robert S. Freeman, Closed extensions of the Laplace operator determined by a general class of boundary conditions, for unbounded regions ......................

Robert E. Fullerton, Geometric structure of absolute basis systems in a linear topological

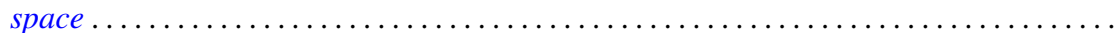

Dieter Gaier, On conformal mapping of nearly circular regions

Andrew Mattei Gleason and Hassler Whitney, The extension of linear functionals defined

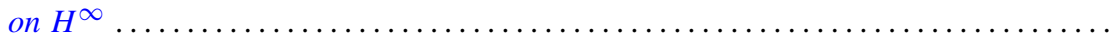

Seymour Goldberg, Closed linear operators and associated continuous linear

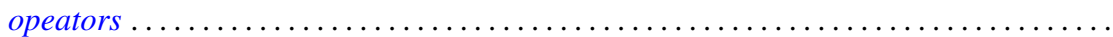

Basil Gordon, Aviezri Siegmund Fraenkel and Ernst Gabor Straus, On the determination of sets by the sets of sums of a certain order

Branko Grünbaum, The dimension of intersections of convex sets. .

Paul Daniel Hill, On the number of pure subgroups

Robert Peter Holten, Generalized Goursat problem . .

Alfred Horn, Eigenvalues of sums of Hermitian matrices ...........

Henry C. Howard, Oscillation and nonoscillation criteria for

$$
y^{\prime \prime}(x)+f(y(x)) p(x)=0
$$

Taqdir Husain, $S$-spaces and the open mapping theorem ...

Richard Eugene Isaac, Markov processes and unique stationary probability measures ...

John Rolfe Isbell, Supercomplete spaces ....................

John Rolfe Isbell, On finite-dimensional uniform spaces. II .........

N. Jacobson, A note on automorphisms of Lie algebras ..............

Antoni A. Kosinski, A theorem on families of acyclic sets and its applications

Marvin David Marcus and H. Minc, The invariance of symmetric functions of singular values...

Ralph David McWilliams, A note on weak sequential convergence.

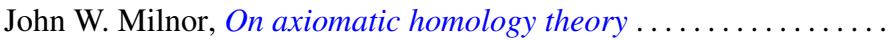

Victor Julius Mizel and Malempati Madhusudana Rao, Nonsymmetric projections in

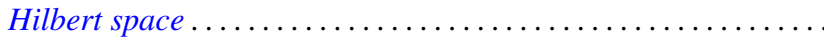

Calvin Cooper Moore, On the Frobenius reciprocity theorem for locally compact

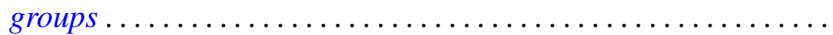

Donald J. Newman, The Gibbs phenomenon for Hausdorff means . 